\title{
Diversity analysis of Bemisia tabaci biotypes: RAPD, PCR-RFLP and sequencing of the ITS1 rDNA region
}

\author{
Aline R. Rabello ${ }^{1,2}$, Paulo R. Queiroz ${ }^{1,2}$, Kenya C.C. Simões ${ }^{1,2}$, Cássia O. Hiragi ${ }^{1,2}$, Luzia H.C. Lima ${ }^{2}$, \\ Maria Regina V. Oliveira ${ }^{2}$ and Angela Mehta ${ }^{2}$ \\ ${ }^{1}$ Universidade de Brasília, Brasília, DF, Brazil. \\ ${ }^{2}$ Embrapa Recursos Genéticos e Biotecnologia, Brasília, DF, Brazil.
}

\begin{abstract}
The Bemisia tabaci complex is formed by approximately 41 biotypes, two of which (B and $\mathrm{BR}$ ) occur in Brazil. In this work we aimed at obtaining genetic markers to assess the genetic diversity of the different biotypes. In order to do that we analyzed Bemisia tabaci biotypes B, BR, Q and Cassava using molecular techniques including RAPD, PCR-RFLP and sequencing of the ITS1 rDNA region. The analyses revealed a high similarity between the individuals of the $B$ and $Q$ biotypes, which could be distinguished from the BR individuals. A phylogenetic tree based on ITS1 rDNA sequence was constructed. This is the first report of the ITS1 rDNA sequence of Bemisia tuberculata and of the BR biotype of $B$. tabaci.
\end{abstract}

Key words: whitefly, ITS rDNA, genetic diversity, phylogenetic analysis.

Received: June 18, 2007; Accepted: January 16, 2008.

Bemisia tabaci (Gennadius) (Hemiptera, Aleyrodidae) is considered one of the most destructive pests in agriculture, causing severe losses in crops around the world, including tropical and subtropical regions. The B. tabaci complex is formed by approximately 41 morphologically indistinguishable biotypes (De Barro et al., 2005).

Brazilian populations of $B$. tabaci were first reported in Bahia in 1929 and by the early 1960s they had become a pest of important cultures (Lima et al., 2002). Further studies, using molecular analyses, were performed and the Brazilian population was designated the BR biotype (Lima et al., 2000). The B biotype was first detected in the USA in the beginning of the 1980's (Costa and Brown, 1990, 1991) and it was introduced in Brazil in the beginning of the 1990's (Lourenção and Nagai, 1994). In the last few years, this biotype has spread to several states in Brazil, causing severe losses (Lima et al., 2002). Another biotype which is attracting an increasing interest worldwide is the $\mathrm{Q}$ biotype. This biotype is exotic to Brazil and is of extreme importance due to its similarity to the B biotype. These biotypes coexist in some areas around the world (Moya et al., 2001), which raises some interesting questions regarding their biological and phylogenetic relationships and the possibility of viable hybrids.

Send correspndence to Angela Mehta. Embrapa Recursos Genéticos e Biotecnologia, Av. W/5 Norte Final, Asa Norte, 70770-900 Brasília, DF, Brazil. E-mail: amehta@cenargen.embrapa.br.
Due to limitations in morphological traits for the identification of the diverse biotypes of $B$. tabaci, the classification of the populations of $B$. tabaci complex is still controversial and molecular techniques have been employed. Initially, esterase locus polymorphisms were used as molecular markers (Brown et al., 1995) and more recently DNA-based techniques such as DNA:DNA hybridization and PCR provided new prospects (Khasdan et al., 2005). RAPD-PCR analysis has been considered a useful technique for the distinction of closely related populations, especially to detect inter and intraspecific differences among Bemisia spp. (Gawell and Bartlett, 1993; Perring et al., 1993; De Barro and Driver, 1997; Khasdan et al., 2005). Other techniques, such as AFLP and RFLP, have also been used to successfully distinguish populations of $B$. tabaci (Cervera et al., 2000). Analyses of the conserved ribosomal and mitochondrial DNA have also been used to infer phylogenetic relationships among $B$. tabaci biotypes (De Barro et al., 2000; Abdullahi et al., 2004).

Studies of the native Brazilian B. tabaci biotype (BR) are scarce and only a few molecular analyses have been performed (Lima et al., 2002). In the present study, we evaluated the genetic diversity of exotic and native Brazilian biotypes in an attempt to establish methods to help to control the arrival of new biotypes.

Seven different populations of Bemisia tabaci, representing the B, BR, Q and Cassava biotypes were analyzed (Table 1). The BR population was pre-classified based on 
Table 1 - Bemisia tabaci populations used in this study.

\begin{tabular}{|c|c|c|c|c|c|}
\hline Biotype/species & $\mathrm{N}$ & Origin & Culture & $\begin{array}{l}\text { Identification } \\
\text { code/individual }\end{array}$ & $\begin{array}{c}\text { Accession } \\
\text { number }\end{array}$ \\
\hline B & $5 / 5 / 1$ & USA, California & Melon & $61 / 1$ & EF173281 \\
\hline B & $4 / 5 / 1$ & Brazil, Balsas, Maranhão & Soybean & $140 / 1$ & EF173278 \\
\hline B & $5 / 5 / 1$ & Brazil, Brasília, Distrito Federal & Tomato & $288 / 1$ & EF173280 \\
\hline Q & $5 / 5 / 1$ & Morocco & Cucumber & $7 / 1$ & EF173284 \\
\hline Cassava & $4 / 5 / 2$ & Nigeria & Cassava & $\begin{array}{l}8 / 1 \\
8 / 2\end{array}$ & $\begin{array}{l}\text { EF173282 } \\
\text { EF173283 }\end{array}$ \\
\hline Q & $5 / 5 / 1$ & Spain & Tomato & $14 / 1$ & EF173279 \\
\hline $\mathrm{BR}$ & $5 / 5 / 1$ & Brazil & Beans & $45 / 1$ & EF173285 \\
\hline A & $4 / 5 / 1$ & USA & Cotton & 62 & - \\
\hline Bemisia tuberculata & $0 / 0 / 1$ & Brazil, Vale do Ivinhema, Mato Grosso do Sul & Cassava & 58 & - \\
\hline $\mathrm{B}^{*}$ & - & USA, Arizona & Cotton & - & AJ 315821 \\
\hline $\mathrm{B}^{*}$ & - & USA, Florida & Tomato & - & AF 216072 \\
\hline $\mathrm{Q}^{*}$ & - & Spain & Cassava & - & AJ 315795 \\
\hline $\mathrm{A}^{*}$ & - & USA, Arizona & Cotton & - & AJ 315796 \\
\hline$A^{*}$ & - & USA, Arizona & Cotton & - & AF 216068 \\
\hline Cassava* & - & Nigeria & Cassava & - & AJ 315819 \\
\hline Cassava* & - & Congo & Cassava & - & AJ 315809 \\
\hline
\end{tabular}

$\mathrm{N}$ : Number of individuals used in RAPD/ PCR-RFLP/sequencing. *Sequences obtained from GenBank.

RAPD primers, as previously described by Lima et al. (2002). The A biotype (population code 62) was included in the RAPD analysis for comparison, since in previous studies this biotype was shown to be closely related to the BR biotype (Lima et al., 2000). The Q and Cassava biotypes were provided by Dr. José Luis Caris (Murcia, Spain) and Dr. Ismail Abdullahi (University of Ibadan, Nigeria), respectively. For comparison purposes, one individual of Bemisia tuberculata (population code 58) was included in the sequencing analysis of the ITS1 rDNA region and was used as the outgroup in the phylogenetic analysis. The individuals of each population were named with the identification code followed by the numbers 1 through 5 .

The populations were first sexed for the selection of female individuals and the DNA was extracted using the method described by Lima et al. (2000). Briefly, the samples were macerated in lysis buffer containing Tris- $\mathrm{HCl} 10$ $\mathrm{mM}$ pH 8.0, EDTA $1 \mathrm{mM}$, Triton X-100 0,30\%, proteinase $\mathrm{K} 60 \mu \mathrm{g} \mathrm{mL}{ }^{-1}$, and were incubated at $65^{\circ} \mathrm{C}$ for $30 \mathrm{~min}$ and at $95^{\circ} \mathrm{C}$ for $10 \mathrm{~min}$. The samples were then stored at $-20^{\circ} \mathrm{C}$ until use.

For the RAPD-PCR analysis, a total of 33 individuals were used including four individuals of the biotypes $\mathrm{B}$ (140) and Cassava (8) and five individuals of the biotypes BR (45), B (61), B (288), Q (7) and Q (14). Four individuals of the biotype A (62) were also included for comparison. The amplifications were performed in a total volume of $30 \mu \mathrm{L}$ containing $0.4 \mu \mathrm{M}$ of primer, $0.2 \mathrm{mM}$ dNTP, $1 \mathrm{U}$ Taq DNA polymerase and $20 \mathrm{ng}$ of DNA. The primers OPA04, OPA10, OPA11 and OPA15 (Operon Technologies, Inc.) were used in this study. The amplification reactions were performed with an initial denaturation at $94^{\circ} \mathrm{C}$ for $3 \mathrm{~min}$, followed by 45 cycles at $93^{\circ} \mathrm{C}$ for $1 \mathrm{~min}, 35^{\circ} \mathrm{C}$ for $1 \mathrm{~min}$ and $72{ }^{\circ} \mathrm{C}$ for $2 \mathrm{~min}$. The RAPD amplification products were separated in $1.5 \%$ agarose gels in TBE $1 \mathrm{X}$ (Tris-borate $90 \mathrm{mM}$ and EDTA $1 \mathrm{mM}$ ). The gels were stained with $5 \mu \mathrm{g} \mathrm{mL} \mathrm{m}^{-1}$ ethidium bromide and the bands were visualized under UV using the EagleEye II still video system $^{\mathrm{TM}}$ (Stratagene). The molecular marker Ladder $100 \mathrm{bp}$ (Invitrogen) was used. At least three replicates were performed for each primer used.

The banding patterns observed were used to construct a dendrogram based on a similarity matrix obtained by the Jaccard's coefficient using the UPGMA (unweighted pair-group method analysis) program. The dendrogram was constructed with the NTSYS (Numerical Taxonomy and Multivariate Analysis System) program version 2.02 pc (Rohlf, 1993).

For the PCR-RFLP analysis of the ITS1 rDNA region, five individuals of each population of the biotypes $\mathrm{B}$ (61, 140 and 288), BR (45), Q (7 and 14) and Cassava (8) were used. The amplification of the ITS1 rDNA region was performed using the primers TW81 (Brust et al., 1998) and 5.8R (De Barro et al., 2000) as described by De Barro et al. (2003), with some modifications. The final volume of the reaction was $30 \mu \mathrm{L}$ containing $2 \mu \mathrm{L}$ of $\mathrm{DMSO}, \mathrm{MgCl}_{2} 50$ $\mathrm{mM}, 5 \mu \mathrm{L}$ of each primer TW81 and 5.8R (2 mM), dNTP $10 \mathrm{mM}$ and $1 \mathrm{U}$ of Taq Polymerase (Pharmacia). The amplifications were performed with an initial denaturation at $94{ }^{\circ} \mathrm{C}$ for $5 \mathrm{~min}$ followed by the addition of Taq Polymer- 
ase. The samples were incubated at $72{ }^{\circ} \mathrm{C}$ for $5 \mathrm{~min}$ and denatured at $95{ }^{\circ} \mathrm{C}$ for $3 \mathrm{~min}$. A 30 cycle amplification was performed with an initial denaturation at $95^{\circ} \mathrm{C}$ for $30 \mathrm{~s}$, annealing at $54{ }^{\circ} \mathrm{C}$ for $1 \mathrm{~min}$ and extension at $72^{\circ} \mathrm{C}$ for $1 \mathrm{~min}$. The amplification product was electrophoresed in a $1.5 \%$ agarose gel and visualized after ethidium bromide staining $\left(0,5 \mu \mathrm{L} \mathrm{mL}{ }^{-1}\right)$. Ladder $100 \mathrm{pb}$ (Invitrogen) was used as a molecular marker.

The amplified ITS1 rDNA region was digested with the restriction enzymes XhoI, BamHI, EcoRI, PstI, AvaI, $D d e I$ and Sau3A. The digestions were performed according to the manufacturers instructions. The fragments obtained were separated by electrophoresis in a $2 \%$ agarose gel and visualized after ethidium bromide staining $\left(0,5 \mu \mathrm{L} \mathrm{mL}^{-1}\right)$. Bands under $100 \mathrm{bp}$ were not considered in the analyses.

The ITS1 rDNA of individuals representing each population $(61,140,288,7,8,14 \mathrm{e} 45)$ and profile obtained by PCR-RFLP $(61 / 1,140 / 1,288 / 1,7 / 1,8 / 1,8 / 2,14 / 1$, $45 / 1$ ), as well as of one individual of Bemisia tuberculata, were cloned in pGem T-Easy (Promega) and sequenced in an automatic sequencer ABI Prism 3700 DNA Analyser
(Applied Biosystems Inc.). Both strands were sequenced and the sequences were deposited in GenBank (Table 1). The alignment of the sequences was performed using the Clustal W program (Higgins et al., 1994). A phylogenetic tree was constructed using the MEGA program version 3.0 (Kumar et al., 2004), with the p-distance and the Neighbor-joining method. Bootstrap analysis was performed with 250 replications. Besides the sequences determined in this study, sequences of the ITS1 rDNA region of some biotypes available in GenBank were also included for comparison (Table 1). The B. tuberculata sequence obtained in this study was used as the outgroup.

The analysis of the amplicons generated by the RAPD reactions revealed that the biotypes of $B$. tabaci produced different molecular patterns (Figure 1A). The banding patterns of the A and BR biotypes were very similar, with several common bands when the four RAPD primers were used. These results agree with previous studies reported by Lima et al. (2002). When using the primer OPA04, for example, it was observed that the A and BR biotypes had a common fragment of $950 \mathrm{pb}$. However, the presence of an additional $800 \mathrm{pb}$ RAPD fragment allowed

OPA 10

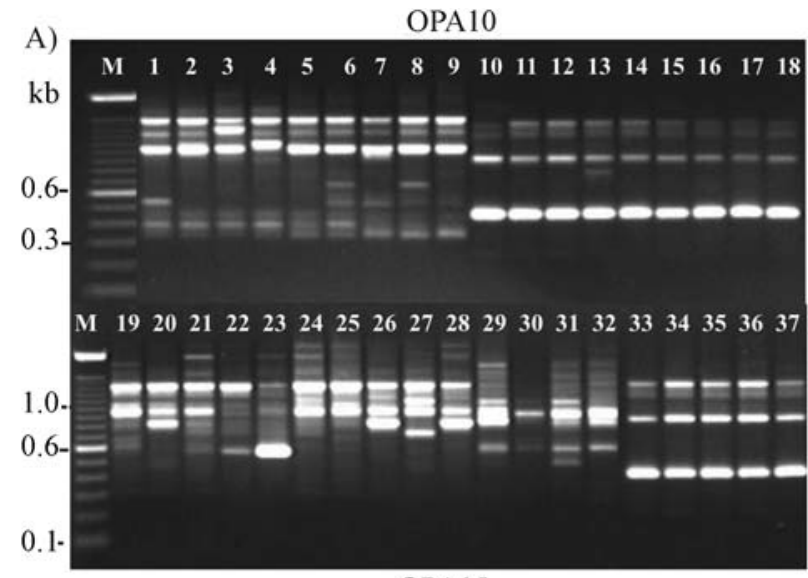

OPA15

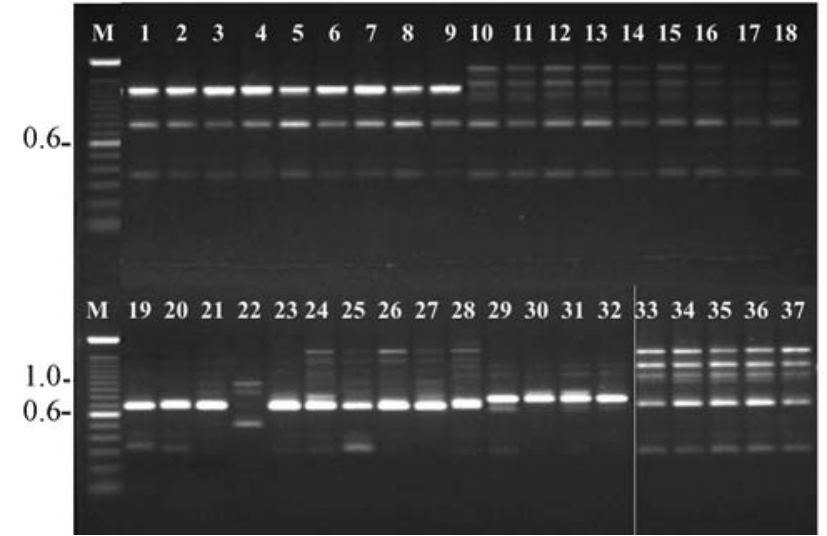

B)

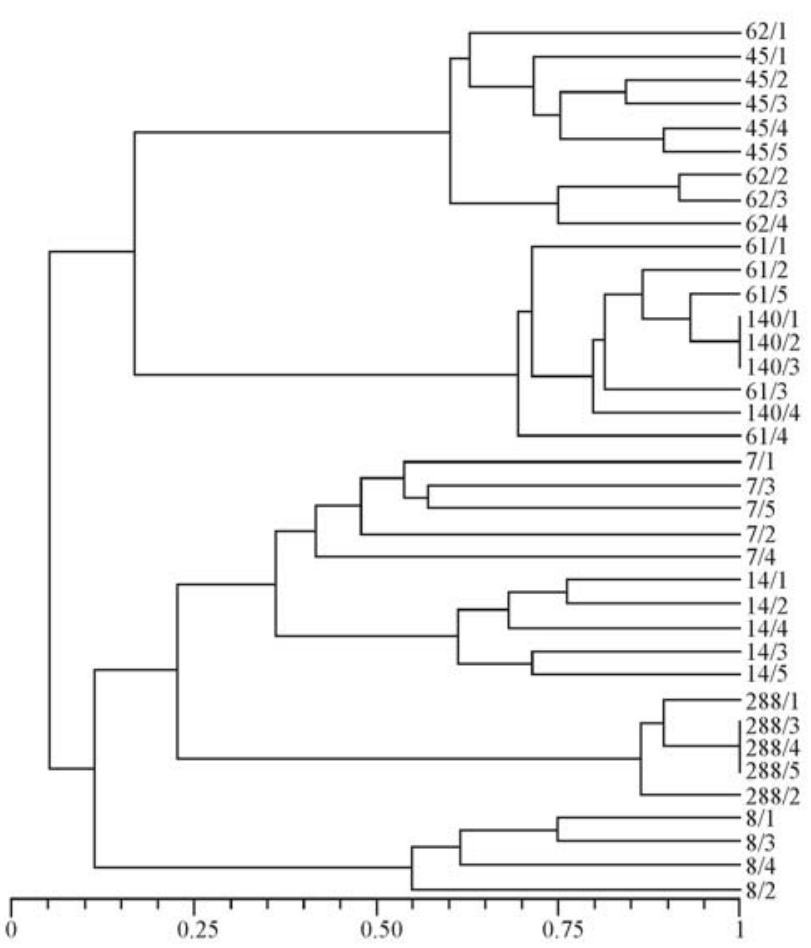

Figure 1 - A) RAPD amplicons produced by the OPA10 and OPA15 primers with DNA from different Bemisia tabaci biotypes. Numbers are: 1-4, A biotype (USA); 5-9, BR biotype (Brazil); 10-14, B biotype collected from melon (USA); 15-18, B biotype from soybean (Brazil); 19-23, Q biotype (Morocco); 24-28, Q biotype (Spain); 29-32, Cassava biotype (Nigeria); 33-37, B biotype collected from tomato (Brazil). M, ladder 100 bp. B) Dendrogram showing the similarity among the populations of the $B$. tabaci complex biotypes, constructed with RAPD data and obtained by a Jaccard's coefficient using UPGMA and NTSYS. 
to discriminate the $\mathrm{BR}$ biotype. Moreover, the $\mathrm{B}$ and $\mathrm{Q}$ biotypes had a similar $700 \mathrm{pb}$ fragment but two bands, one with $550 \mathrm{pb}$ and another with $900 \mathrm{pb}$, were only present in the $\mathrm{Q}$ biotype. The amplified fragments can be further explored to develop specific primers which can be used as molecular markers for a rapid and accurate identification of B. tabaci biotypes.

Variation in the RAPD profiles was found among the B biotype from different hosts using the OPA04, OPA10 and OPA11 primers. A higher level of diversity was found within the populations of the $\mathrm{Q}$ and Cassava biotypes when the OPA10 and OPA11 primers were used. On the other hand, the OPA 15 primer revealed a lower level of diversity among the $B$. tabaci populations.

The combined data sets obtained with the four primers were used to construct a dendrogram, which showed a high level of diversity among the $B$. tabaci biotypes and allowed the distinction of seven major clusters (Figure 1B). The first group (group I) was composed by the Brazilian biotype (BR) and the American biotype (A) populations. These populations showed $15 \%$ similarity in relation to group II, formed by the B biotype populations of soybean and melon. The third group (group III) was composed of Q biotype individuals from Morocco. Unexpectedly, one individual (7/4) formed a separate group (group IV) distantly related to the other Q biotype individuals from Morocco and presented a very distinct RAPD profile with the OPA15 primer. A high level of diversity has been previously reported in Q biotype populations (Moya et al., 2001).

Group V was formed by Q biotype individuals from Spain. Interestingly, one B biotype population of $B$. tabaci (288) collected from tomato in Brazil (group VI) showed a higher similarity to Cassava and Q biotypes from Spain. Another intriguing result was that population 288 did not group with the other B biotype populations (61 and 140). It is possible that population 288 is older and had more time to differentiate from the originally introduced population from the USA. Some authors suggest that isolation is the key mechanism that leads to genetic diversity (De Barro et al., 2005). Group VII was composed by the Cassava biotype of $B$. tabaci, which differs from the other biotypes in its host specificity (Abdullahi et al., 2003, 2004).

Overall, the populations analyzed in this study were grouped according to their biotypes, showing that RAPD was useful to distinguish the biotypes that occur in Brazil as well as the exotic ones. This technique can be further explored in order to design specific primers to rapidly identify new biotypes, which can be very useful as an identification tool to be used for quarantine and phytosanitary purposes.

The analysis of the ITS rDNA region was performed in an attempt to obtain another method for the identification of $B$. tabaci biotypes. The ITS rDNA is a conserved region and is useful in distinguishing recently divergent taxa (De Barro et al., 2003). The amplification of the ITS1 rDNA region of the $B$. tabaci populations revealed one band of ap- proximately $550 \mathrm{bp}$ for all the individuals analyzed. The amplification product was digested with seven restriction enzymes. No digestion was observed when the enzymes XhoI, BamHI, EcoRI and PstI were used and different banding patterns were observed after digestion with DdeI, $A v a \mathrm{I}$ and Sau3A (Figure 2A).

The individuals of the $\mathrm{B}$ biotype populations from the USA and Brazil, as well as those of the Q biotype populations from Morocco and Spain showed identical banding patterns with the three enzymes (Figure 2A). An intrapopulation variation was observed in the Cassava biotype from Nigeria (Figure 2A). One of the five analyzed individuals from this population (8/1) presented a banding pattern identical to that of the B and Q biotypes from Spain and Morocco, while the other four individuals revealed a unique profile for the three enzymes used. The ITS rDNA region of these four individuals did not present a restriction site for the DdeI enzyme. The native Brazilian BR biotype also showed the same restriction pattern observed for the $B$ and Q biotype populations with the three enzymes used (Figure 2A).

For a more detailed analysis of the divergence level of the ITS1 rDNA region between the populations and biotypes, the sequence of the ITS1 rDNA of one individual representing the populations and groups obtained by the PCR-RFLP analysis was determined. Sequences varying between 542 and 555 bp were obtained and aligned using the Clustal W program (Higgins et al., 1994). The alignment of the sequences revealed a high similarity between the individuals of the different biotypes which ranged between $100 \%$ and $93,8 \%$. The individuals of the B biotype presented almost identical sequences, differing only in positions 219 and 414. The BR biotype presented approximately $95 \%$ similarity with the other biotypes, including biotype B, which is dominant in Brazil. The individual 8/2 of the Cassava biotype from Nigeria presented the most divergent ITS1 rDNA sequence. Unexpectedly, the sequences of the BR and Cassava (8/2) biotypes presented a six-base insertion at position 239 of the ITS rDNA sequence. This region may be used to design specific primers that distinguish these biotypes. The ITS rDNA region of one B. tuberculata individual (58/1) (EF173286) was also determined and showed low similarity with the sequences of B. tabaci biotypes (66\% to $64 \%$ ). Interestingly, the $B$. tuberculata ITS rDNA sequence presented a 17-base deletion at position 89 and this region can also be used to design specific primers to rapidly identify $B$. tuberculata.

A phylogenetic tree was constructed using the ITS1 rDNA sequences herein obtained and sequences of individuals of the A, Q and B biotypes available in GenBank (Figure 2B; Table 1). The phylogenetic tree presents three major groups: one formed by the individuals of biotypes B from Brazil and the USA and Q from Spain, Morocco and Cassava (individual 8/1); a second group formed by biotypes A and BR, and a third group composed of individuals 
(A)

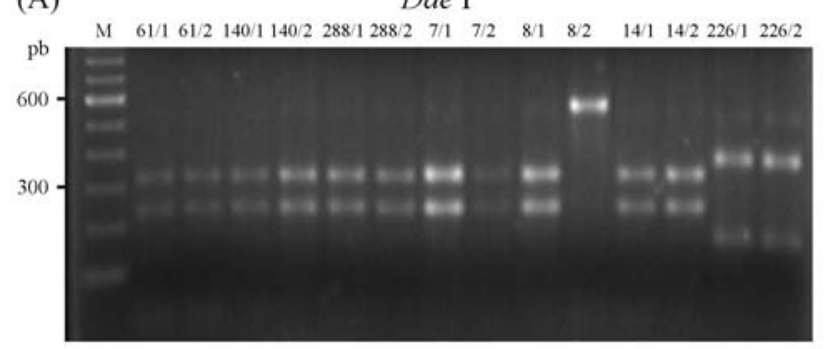

Ava I

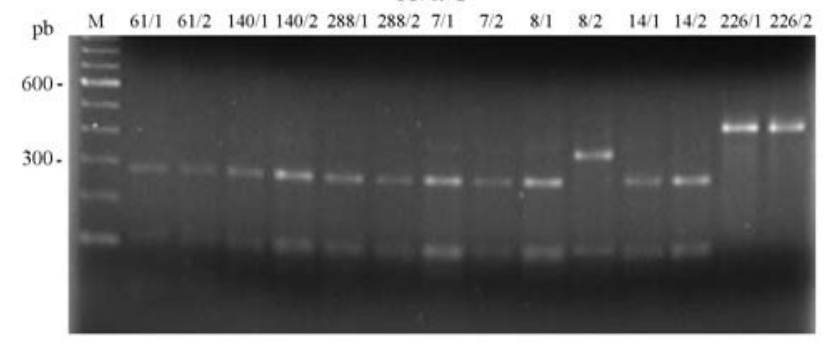

Sau3A

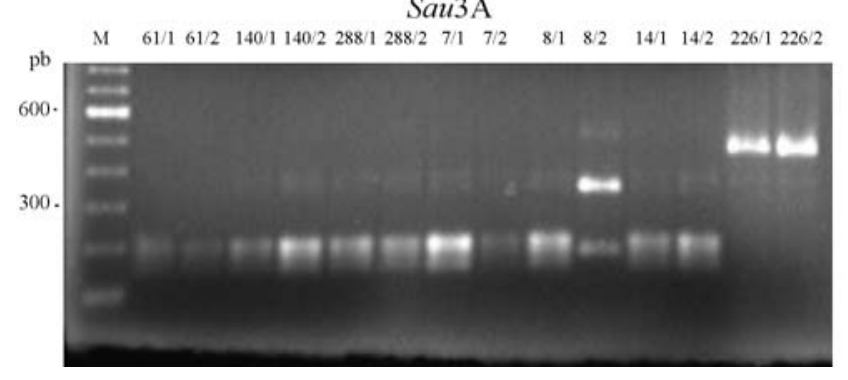

(B)

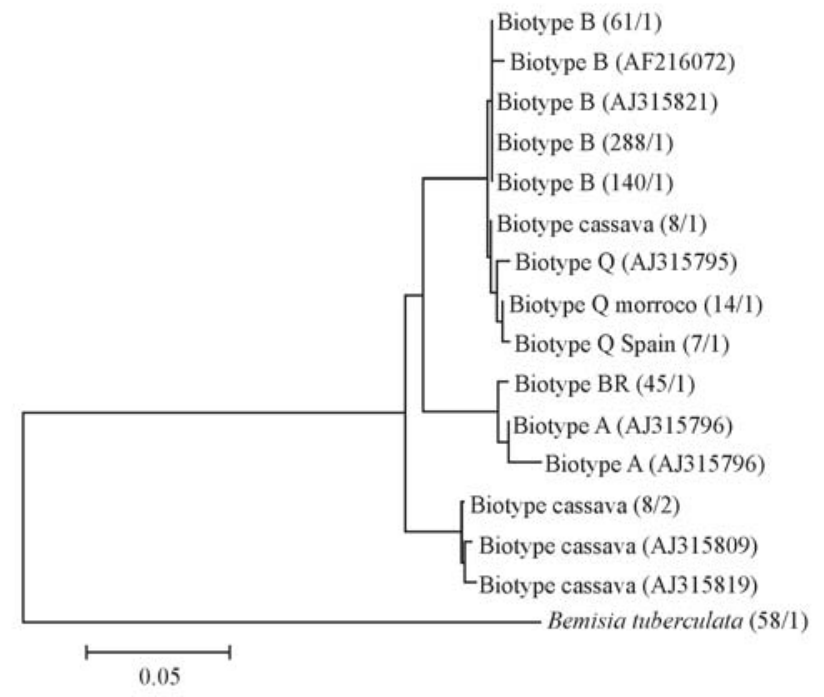

Figure 2 - A) Digestion of the Bemisia tabaci ITS1 rDNA region with the restriction enzymes Dde I (A), Ava I (B) and Sau3A (C). 61, B biotype collect from melon (USA); 140, B biotype from soybean (Brazil); 288, B biotype collected from tomato (Brazil); 7, Q biotype (Morocco); 8, Cassava biotype (Nigeria); 14, Q biotype (Spain). B) Phylogenetic tree of the different Bemisia tabaci biotypes and populations listed in Table 1, with the bootstrap values over the branches. The tree was constructed using the Neighbor-joining method with MEGA version 3.0. The bar indicates the distance value.

of the Cassava biotype from Nigeria (individual 8/2) (Figure 2B). Interestingly, the individual $8 / 1$ of the Cassava biotype grouped with the $\mathrm{Q}$ biotype indicating that these biotypes possibly coexist and were therefore collected together from the same host plant. In general, the bootstrap values were high, mostly above $98 \%$, indicating a high reliability in the obtained grouping. Similar results were observed by De Barro et al. (2000) when analyzing the ITS1 rDNA region of different biotypes. These authors reported that the populations of America (biotype A) formed a group closely related to the B biotype and to the biotypes from Northern Africa.

The results obtained herein showed that the analysis of the ITS1 rDNA region constitutes a valuable method, complementary to RAPD-PCR, that allows the inference of the relationships between species and biotypes of $B$. tabaci. Moreover, several differential bands detected in the RAPD-PCR and specific sequences of the ITS rDNA can be further explored to develop specific primers to rapidly and efficiently distinguish the $B$. tabaci biotypes. The use of specific primers represents an important tool as it may help to avoid the introduction of exotic biotypes of $B$. tabaci in Brazil. This is of interest because invasive alien species or biotypes may cause a severe economic, environmental and social impact in agricultural crops.

\section{Acknowledgments}

We thank Dr. Ismail Abdullahi from the Department of Plant Protection and Environmental Biology of the University of Ibadan, Nigeria, and Dr. José Luis Caris, Murcia, Spain, for providing the $B$. tabaci Cassava and Q biotype samples.

\section{References}

Abdullahi I, Winter S, Atiri GI and Thottappilly G (2003) Molecular characterization of whitefly, Bemisia tabaci (Hemiptera, Aleyrodidae) populations infesting cassava. Bull Entomol Res 93:97-106.

Abdullahi I, Atiri GI, Thottappilly G and Winter S (2004) Discrimination of cassava-associated Bemisia tabaci in Africa from polyphagous populations, by PCR-RFLP of internal transcribed spacer regions of ribossomal DNA. J Appl Entomol 128:81-87.

Brown JK, Coats SA, Bedford ID, Markham PG, Bird J and Frohlich DR (1995) Characterization and distribution of esterase electromorphs in the whitefly, Bemisia tabaci 
(Genn.) (Homoptera, Aleyrodidae). Biochem Genet 33:205-214.

Brust RA, Ballard JWO, Driver F, Hartley DM, Galway NJ and Curran J (1998) Molecular systematics, morphological analysis, and hybrid crossing identify a third taxon, Aedes (Halaedes) wardandensis sp. nov., of the Aedes (Halaedes) australis species-group (Diptera, Culicidae). Can J Zool 76:1236-1246.

Cervera MT, Cabezas JA, Simon B, Martinez-Zapater JM, Beitia $\mathrm{F}$ and Cenis JL (2000) Molecular characterization of whitefly, Bemisia tabaci (Hemiptera, Aleyrodidae) population infesting cassava. Bull Entomol Res 90:91-396.

Costa HS and Brown JK (1990) Variability in biological characteristic isozyme patterns and virus transmission among populations of Bemisia tabaci Genn. in Arizona. Phytopathology 80:888.

Costa HS and Brown JK (1991) Variation in biological characteristics and esterase patterns among populations of Bemisia tabaci, and the association of one population with silverleaf symptom induction. Entomol Exp Appl 61:211-219.

De Barro PJ and Driver F (1997) Use of RAPD PCR to distinguish the B biotype from other biotypes of Bemisia tabaci (Gennadius) (Hemiptera, Aleyrodidae). Austr J Entomol 36:149-152.

De Barro PJ, Driver F, Trueman JWH and Curran J (2000) Phylogenetic relationships of world populations of Bemisia tabaci (Gennadius) using ribosomal ITS1. Mol Phylogenet Evol 16:29-36.

De Barro PJ, Scott KD, Graham GC, Lange CL and Schutze MK (2003) Isolation and characterization of microsatellite loci in Bemisia tabaci. Mol Ecol Notes 3:40-43.

De Barro PJ, Trueman JWH and Frohlich DR (2005) Bemisia argentifolii is a race of $B$. tabaci: The molecular genetic differentiation of B. tabaci populations around the world. Bull Entomol Res 95:193-203.

Gawell NJ and Bartlett AC (1993) Characterization of differences between whiteflies using RAPD-PCR. Insect Mol Biol 2:33-38.
Higgins D, Thompson J, Gibson T, Thompson JD, Higgins DG and Gibson TJ (1994) CLUSTAL W: Improving the sensitivity of progressive multiple sequence alignment through sequence weighting, position-specific gap penalties and weight matrix choice. Nucleic Acids Res 22:4673-4680.

Khasdan V, Levin I, Rosner A, Morin S, Kontsedalov S, Maslenin L and Horowitz AR (2005) DNA markers for identifying biotypes B and Q of Bemisia tabaci (Hemiptera, Aleyrodidae) and studying population dynamics. Bull Entomol Res 95:605-613.

Kumar S, Tamura K and Nei M (2004) MEGA3: Integrated software for molecular evolutionary genetics analysis and sequence alignment. Brief Bioinform 5:150-163.

Lima LHC, Návia D, Inglis PW and Oliveira MRV (2000) Survey of Bemisia tabaci (Gennadius) (Hemiptera, Aleyrodidae) biotypes in Brazil using RAPD markers. Genet Mol Biol 23:1-5.

Lima LHC, Campos L, Moretzsohn MC, Návia D and Oliveira MRV (2002) Genetic diversity of Bemisia tabaci (Genn.) populations in Brazil revealed by RAPD markers. Genet Mol Biol 25:217-223.

Lourenção AL and Nagai H (1994) Surtos populacionais de Bemisia tabaci no Estado de São Paulo. Bragantia 53:53-59 (Abstract in English).

Moya A, Guirão P, Cifuentes D, Beitia F and Cenis JL (2001) Genetic diversity of Iberian populations of Bemisia tabaci (Hemiptera, Aleyrodidae) based on random amplified polymorphic DNA-polymerase chain reaction. Mol Ecol 10:891-897.

Perring TM, Cooper AD, Rodriguez RJ, Farrar CA and Bellows Jr. TS (1993) Identification of a whitefly species by genomic and behavioural studies. Science 259:74-77.

Rohlf FJ (1993) NTSYS-pc, numerical taxonomy and multivariate analysis system. v. 1.80. Appl Biostatistics Inc., NY.

Associate Editor: Louis Bernard Klaczko

License information: This is an open-access article distributed under the terms of the Creative Commons Attribution License, which permits unrestricted use, distribution, and reproduction in any medium, provided the original work is properly cited. 